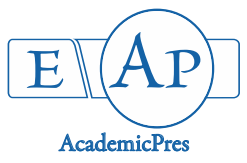

Benabdesslem Y et al. (2020)

Notulae Scientia Biologicae 12(3):673-682

DOI: $10.15835 / \mathrm{nsb} 12310788$

Research Article

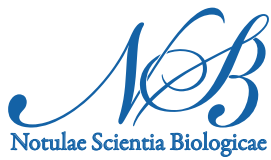

\title{
Callogenesis in Cicer arietinum and identification of a genotype resistant to Ascochyta rabiei
}

\author{
Yasmina BENABDESSLEM ${ }^{1,2 *}$, Kadda HACHEM ${ }^{1,2}$, Samia GHOMARI ${ }^{3}$ \\ ${ }^{1}$ University of Saida Dr. MoulayTahar, Faculty of Science, Laboratory of Biotoxicology, Pharmacognosy and Biological Valorization \\ Plant (LBPVBP), BP 138 citéENNASR, Saida, Algeria; benabdesslem.yasmina@univ-saida.dz ("corresponding author) \\ ${ }^{2}$ University of Saida Dr. Moulay Tahar, Department of Biology, BP 138 cité ENNASR, Saida, \\ Algeria; hachem.kadda@univ-saida.dz \\ ${ }^{3}$ University of Sidi-Bel-Abbès Djillali Liabès, Faculty of Natural and Life Sciences, BP 89, 22000 Sidi-Bel-Abbès, \\ Algeria; samiaghomari22@gmail.com
}

\begin{abstract}
The chickpea (Cicer arietinum) is one of the leguminous species most appreciated by consumers in the Mediterranean basin, while being an important source of protein. Nevertheless, its crop yields are greatly limited by several biotic and abiotic stresses, the main one being Ascochyta rabiei, the causal agent of anthracnose. As traditional breeding methods have proved to be ineffective in controlling this pathogen, resorting to biotechnological methods is necessary. Therefore, in this study, the callogenic capacity of stem and leaflet explants from three genotypes of chickpea, namely 'FLIP 84-92 C', 'ILC 32-97', and 'ILC 263', cultured on Murashige and Skoog (MS) medium with different hormonal balances of auxins (indole-3-acetic acid [IAA] and 2,4-dichlorophenoxyacetic acid [2,4-D]) and cytokinin (kinetin), was determined. For all the genotypes, high percentages of callogenesis were recorded in the different explants grown on an MS medium with $2 \mathrm{mg}$ of both IAA and kinetin. Then, a patho-system of Cicer arietinum calluses with Ascochyta rabieiwas investigated, followed by a histological assessment of this interaction. The presence of the fruiting bodies of the pathogen was revealed in the calluses of the 'ILC 32-97' and 'ILC 263' genotypes. Notably, the latter showed a high sensitivity to the pathogen, as indicated by an abundance of pycnidia in its tissues. As for the 'FLIP 84-92 C' genotype, the histological sections showed a total absence of inter- and intracellular fruiting bodies of the pathogen in the callus tissues. Therefore, this genotype was considered as resistant to Ascochyta rabiei.

Keywords: chickpea; histology; hormone balance; legume: pathogen

\section{Introduction}

The chickpea, Cicer arietinum, in addition to its great economic and ecological interest, is one of the legumes most appreciated by consumers in the Mediterranean basin. Moreover, it is a very important source of proteins, vitamins, minerals, and fibers, especially within the poorest social groups. It is also an interesting crop in alternative agriculture because of its capacity to fix nearly $70 \%$ of atmospheric nitrogen, thanks to a symbiotic relationship established with Rhizobium ciceri (Zaman et al., 2010).
\end{abstract}


Anthracnose is considered one of the most devastating diseases affecting chickpea. Its causative agent Ascochyta rabiei (Teleomorph Didymella rabiei) is a pleomorphic imperfect fungus, which has two stages of reproduction in its life cycle (Lepoivre, 2003). The existence of these two forms favors the continual appearance of new pathotypes, making the selection of stable genotypes resistant to anthracnose almost impossible when using conventional methods.

In order to control anthracnose until its eradication, it is imperative to understand the defense mechanisms deployed by the host cells. This is where green biotechnology comes in, offering opportunities and advantages through in vitro tissue culture techniques and opening up new perspectives in plant pathology. The major advantage of these techniques is the use of organs, tissues, or cells as hosts (Jang and Tainter, 1990; Daayf et al., 2003), which provides a relatively simple and easy-to-use system to study the interaction between a pathogen and its host, such as Ascochyta rabiei and Cicer arietinum, respectively.

In in vitro tissue culture, especially callogenesis, the phenomenon of somaclonal variation is quite common. This genetic variability is a source of interesting traits for plant breeding (Shahab-ud-din et al., 2011). However, this promising pathway requires the development of a standardized and reliable protocol. In legumes such as Cicer arietinum, this remains difficult given their recalcitrant nature (Naz et al., 2008; Ochatt et al., 2010). For instance, hormonal induction of callogenesis in this species has long faced the obstacle of callus recalcitrance, as reported in several studies (Anwaret al., 2010; Zaman et al., 2010; Zare Mirakabad et al., 2011).

The initiation of callogenesis depends on several factors, including the nature and concentration of growth hormones added to the culture medium, the genotype that is studied, and the organs used to collect the cultured explants (Savita et al., 2010). With the aim to select clones resistant to anthracnose, we first studied the effect of different factors on the induction of callus formation to determine the conditions that are favorable to callogenesis in Cicer arietinum. Then, we compared the calluses obtained after inoculation with a strain of Ascochyta rabiei in order to highlight, with a histological approach, the mechanisms induced in the different genotypes following callus-pathogen interaction.

\section{Materials and Methods}

\section{Plant material}

Seeds of three genotypes of Cicer arietinum, namely 'FLIP 84-92 C', 'ILC 32-97', and 'ILC 263', were used as the plant material. They were grown in $12 \times 12 \mathrm{~cm}$ pots, containing a mixture of soil and potting soil $(3: 1, v / v)$, previously autoclaved. Each pot contained 3 seeds. Cultivation was carried out in a greenhouse, where the plants were watered daily.

\section{Growing media}

Basic Murashige and Skoog (1962; MS) media were used, with two different combinations and three different concentrations of hormones (Table 1). The different media contained $30 \mathrm{~g} \mathrm{~L}^{-1}$ of sucrose and were solidified with $10 \mathrm{~g} \mathrm{~L}^{-1}$ of agar-agar. The $\mathrm{pH}$ was adjusted to 5.8 before autoclaving.

\section{Induction of callogenesis}

Callogenesis was initiated in leaf and stem explants of about $8 \times 5 \mathrm{~mm}$ and $5 \mathrm{~mm}$ in length, respectively, taken from plants aged 3 weeks. The explants were disinfected by immersion in $70^{\circ}$ ethanol for 30 seconds and then in an $8 \%$ calcium hypochlorite solution for 1 minute, which was followed by three rinses with sterile distilled water.

The two types of explant combined with the three genotypes were distributed in a device, with ten explants per hormonal combination and five independent replicates, that is, 50 observations for each treatment. Incubation was carried out at $25^{\circ} \mathrm{C} \pm 2{ }^{\circ} \mathrm{C}$ under a $16 \mathrm{~h}$ photoperiod. The response of the explants was monitored regularly and the effect of the different hormone combinations was evaluated after 4 weeks. The 
percentage was calculated on the basis of the number of calluses obtained in relation to the total number of explants.

Table 1. Hormonal combinations added to Murashige and Skoog (MS) media for the initiation of callogenesis in Cicer arietinum

\begin{tabular}{|c|c|c|c|}
\hline \multirow{2}{*}{ Culture media } & \multicolumn{3}{|c|}{ Hormone } \\
\cline { 2 - 4 } & $\begin{array}{c}\text { Indole-3-acetic acid } \\
\text { (IAA) }\end{array}$ & Kinetin & $\begin{array}{c}\text { 2,4-dichlorophenoxyacetic } \\
\text { acid (2,4-D) }\end{array}$ \\
\hline MS1 & 0,1 & 0,1 & - \\
\hline MS2 & 1 & 1 & - \\
\hline MS3 & 2 & 2 & 0,1 \\
\hline MS4 & - & 0,1 & 1 \\
\hline MS5 & - & 2 & 2 \\
\hline MS6 & - & & \\
\hline
\end{tabular}

\section{Fungal material and inoculum preparation}

The Ascochyta rabiei inoculum came from a monosporic culture obtained from plants of Cicer arietinum affected by anthracnose and collected in the region of Sidi Bel Abess in Western Algeria. The fungus was grown on a chickpea-based medium (i.e., $50 \mathrm{~g}$ of chickpea, $20 \mathrm{~g}$ of glucose, and $12 \mathrm{~g}$ of agar-agar per liter of distilled water). The $\mathrm{pH}$ of the medium was adjusted to 5.8 and the incubation was carried out at an ambient temperature of $23^{\circ} \mathrm{C} \pm 2{ }^{\circ} \mathrm{C}$ and a photoperiod of 12 hours. A fragment of a young culture of the pathogen was taken from a tube containing $10 \mathrm{~mL}$ of sterile distilled water and the spores were released by vortex agitation. Dilutions were made from the first prepared suspension, after counting the rests of Malassez cells, to obtain a final suspension of 106 spores $\mathrm{mL}^{-1}$ (Figure 1).
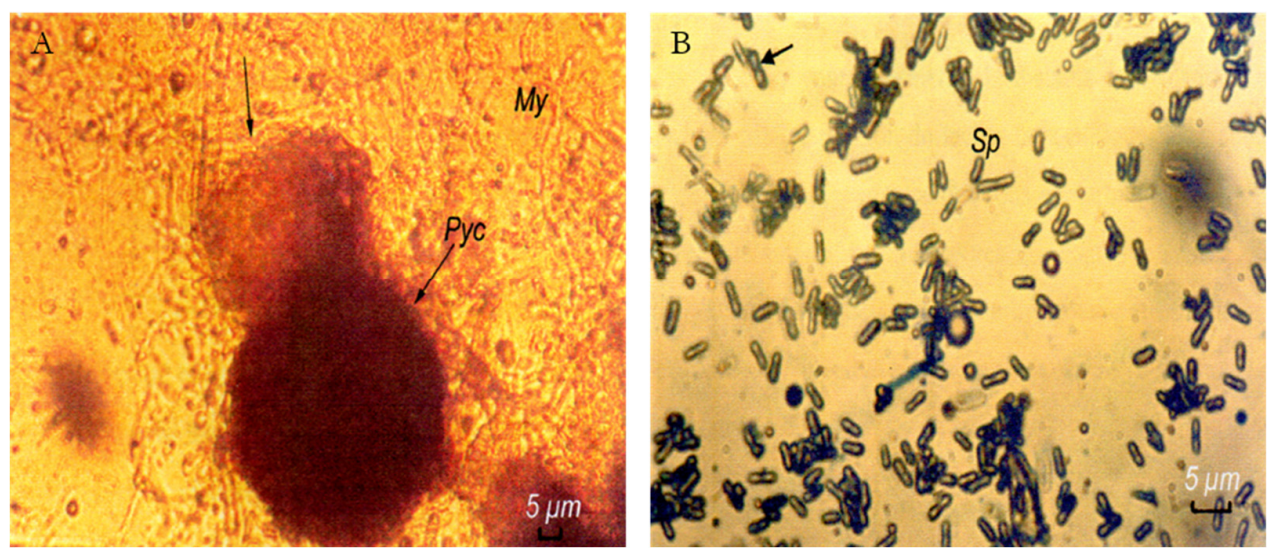

Figure 1. Microscopic features of Ascochyta rabiei: (A) mature pycnidia with cirrus release; (B) single and bicellular pycnidiospores of Ascochyta rabiei

Pyc: pycnidia; My: mycelium; Sp: spores

\section{Callus inoculation and histological assessment of host-pathogen interaction}

Calluses from the different genotypes and explants were inoculated by spreading the suspension of Ascochyta rabieispores $\left(10^{6}\right.$ spores $\left.\mathrm{mL}^{-1}\right)$. The pathosystems thus prepared were cultured after transplantation on MS media free of hormones, and under the same incubation conditions as those of the pathogen. Uninoculated calluses of the two types of explants, for each of the three genotypes that were studied, were used as controls. The host-pathogen interaction was assessed with a histological study to evaluate the degree of microbial proliferation and its effect on callus cells. 
Calluses were fixed in a mixture of glacial acetic acid ethanol (3:1v/v) for 24 hours. The samples were then dehydrated and embedded in paraffin. Serial sections of 7-10 $\mu \mathrm{m}$ were made with a Spencer 820 microtome (Bethlehem, Pennsylvania). Finally, the dew axing, rehydration, and mordanting steps were performed to stain the tissues with Regaud's hematoxylin.

\section{Results}

Effects of hormone combination and genotype on the callogenic potential of Cicer arietinum

After one week of cultivating the explants, they began to show changes in size, while acquiring new structure. These modifications were mainly due to the action of the growth substances used. After 20 days, the explants had produced calluses, cellular clusters with strong mitotic activity.

The explants of stems and leaflets from the three genotypes of Cicer arietinum, namely 'FLIP 84-92 C', 'ILC 32-97', and 'ILC 263', showed reactivity to culture media. Stem explants swelled as a result of internal cell division, whereas this formation occurred over the entire surface of the leaf blade, along the main vein or in the excision areas, in leaflets. After four weeks, the calluses that had formed showed variable characteristics, with different colors and textures depending on the hormonal combination added to the medium. Regardless of genotype, organ, and hormone concentration, the calluses evolving on the media MS1, MS2, and MS3 were green in color and compact in texture. As for the calluses formed on the media MS4, MS5, and MS6, they were friable and yellow to green in color.

The recorded rates of callogenesis in the different explants, namely the stems and leaflets of the three genotypes that were tested, varied according to the concentration, the hormonal combination, and the nature of the explant, and were expressed as the percentage of formed callus (Figure 2).

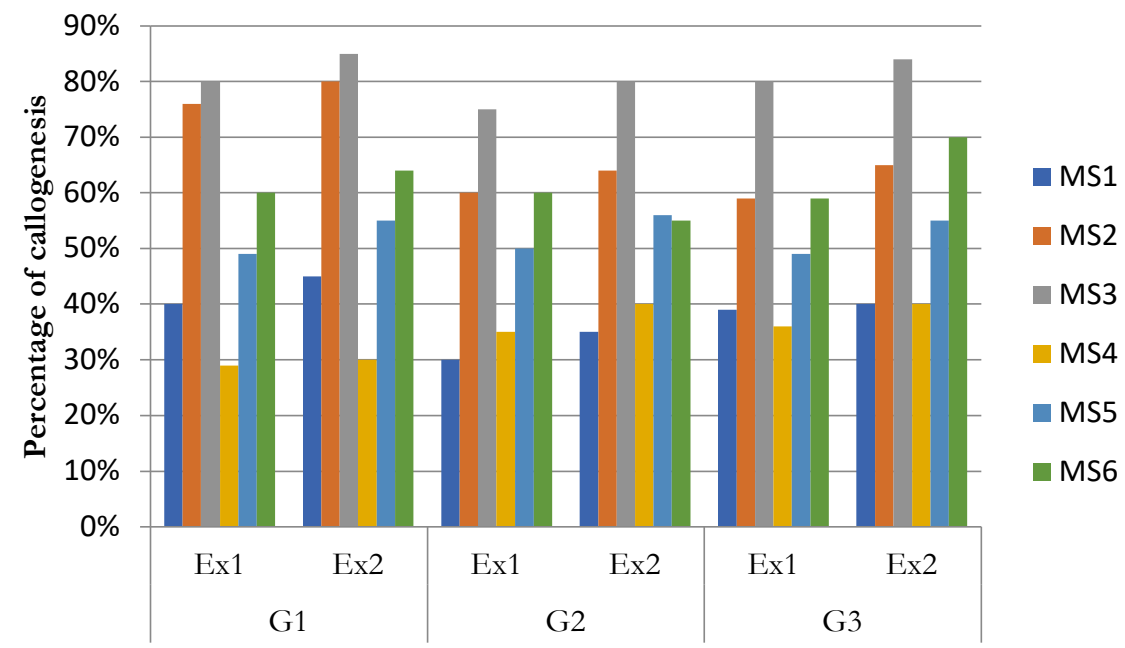

Figure 2. Effect of hormone balance, genotype, and explant type on the callogenesis of Cicer arietinum G1: FLIP 84-92C, G2: ILC 32-97, G3: ILC 263

Ex 1: leaflet explants, Ex 2: stem explants

Notably, the induction of callogenesis in Cicer arietinum was not influenced by the genotype. Moreover, we recorded very similar percentages of callogenesis, namely between $30 \%$ and $40 \%$, for the leaflet explants in low hormone concentration media (i.e., MS1 and MS2), whereas the expression of callogenic potential was higher in stem explants, with percentages between $35 \%$ and $40 \%$ (Figure 2).

In contrast to the genotype and explant type, the initiation of callogenesis in Cicer arietinum was strongly influenced by the hormonal combination and the concentration of hormones in the culture medium. 
All the hormonal combinations, with their different hormone concentrations, induced callogenesis. However, the media (i.e., MS3 and MS6) containing high concentrations of auxin and cytokinin, namely $2 \mathrm{mg}$ of both the auxin and the cytokinin, generated elevated levels of callogenesis. The overall callogenic potential recorded in the MS3 medium varied between $75 \%$ and $85 \%$, while it was of the order of $55 \%$ to $70 \%$ in the MS6 medium.

Therefore, among the different hormonal combinations that were tested, the MS3 medium contained the growth regulator combination that was the most adapted to Cicer arietinum, namely $2 \mathrm{mg}$ of both IAA and kinetin. In these medium, high rates of callogenesis were recorded regardless of the genotype and the nature of the explant (Figure 2).

\section{Histology of control calluses}

The histological study of the control calluses showed that they had the usual constitution of neoformed tissues, that is, masses of parenchymal cells of different sizes, and consisted in compact, meatus-free parenchyma composed of polygonal cells (Figure 3). Some calluses also had xylem elements, notably tracheids, which were interspersed with large polygonal cells.

Furthermore, a few clusters of cells with a more or less rounded shape were observed. These cells, with a high nucleoplasmic ratio, were generally isodiametric with the presence of a granular nucleus, large and hyperchromatized (Figure 3A). This structure is reminiscent of that of embryonic cells and its shape is that of a primordium (Figure 3 ).

The persistence of pre-existing tissues, namely the leaf epidermis (i.e., stomata and hairs) and the leaf conducting tissue, was also observed in leaf callus (Figure 3B).
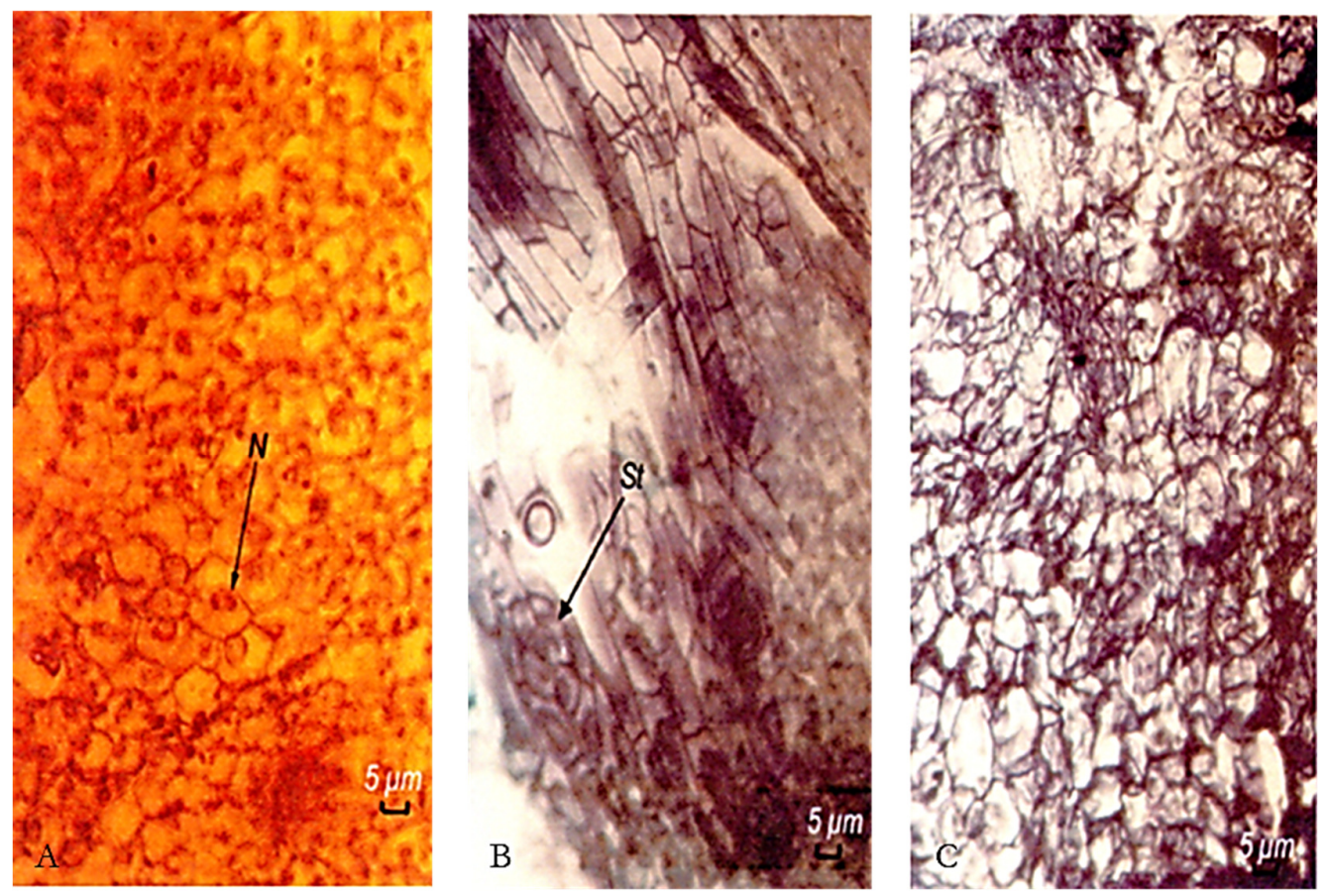

Figure 3. Microscopic observations of control callus tissues from different genotypes, obtained after 4 weeks of culture on an MS medium

(A) Isodiametric cells with granular and enlarged central nuclei (i.e., dedifferentiated embryonic cells). (B) Persistence of leaf tissue with the presence of stomata in the epidermal tissue. (C) Callus formed by dedifferentiated cells; absence of cell content

$\mathrm{N}$ : nucleus; St: stomata 


\section{Histology of calluses inoculated with the pathogen}

The interaction between the callus of Cicer arietinum and the strain of Ascochyta rabiei resulted in a mycelial proliferation, observed 48 hours after inoculation, in the different genotypes tested.

Histological sections clearly showed that the host callus tissues had been invaded by pathogen structures, namely pycnidia and pycnidiospores. Fungal proliferation was limited to one or two pycnidia for the 'ILC3297' genotype (Figure 4B), whereas it was greater in explants of the 'ILC263' genotype, as illustrated by a higher number of pycnidia and intercellular invasion of pycnidiospores (Figure $4 \mathrm{C}$ ). This indicated that the 'ILC 3297 ' genotype is partially resistant to Ascochyta rabiei, while the 'ILC 263 ' genotype is highly sensitive to this pathogen. Moreover, this sensitivity was marked by a significant lysis of the cells surrounding the structures of the pathogen, namely pycnidia and mycelia (Figure 4C2). In contrast, tissue formation in the 'FLIP 84 -92 C' genotype explants did not reveal any inter- or intracellular presence of the pathogen (i.e., absence of pycnidia and pycnidiospores). Notably, this lack of fungal proliferation implies that this genotype is resistant to the pathogen.
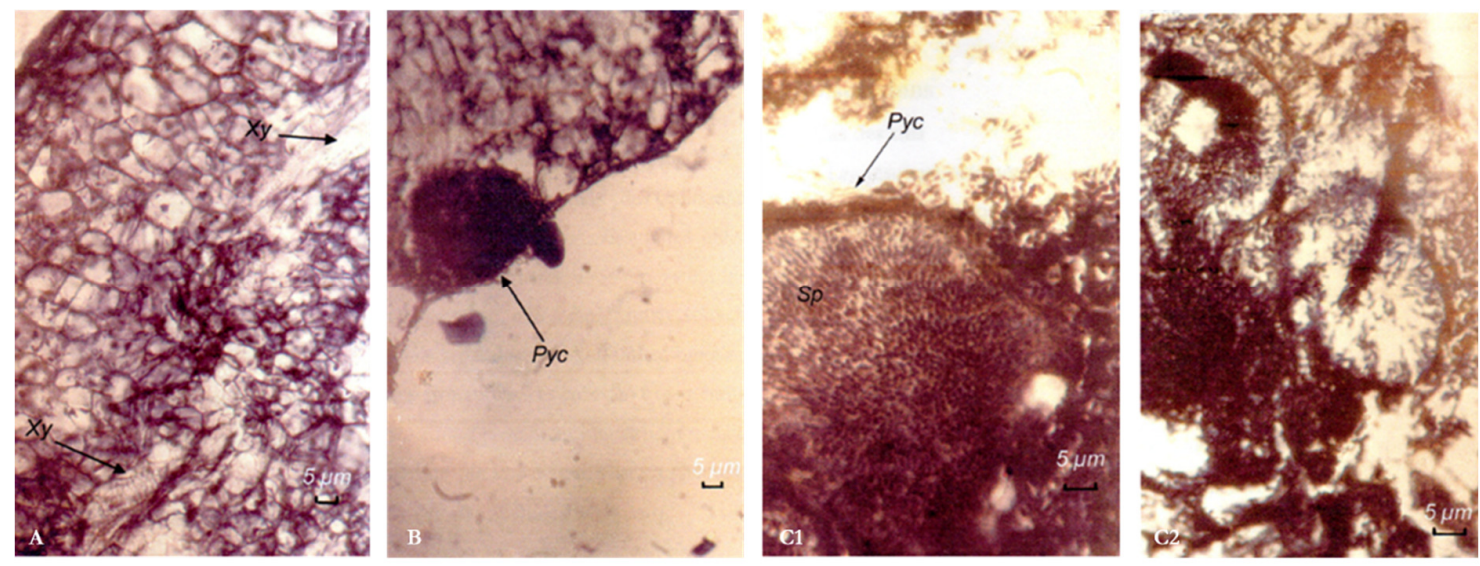

Figure 4. Microscopic observations of callus tissues from different genotypes inoculated with Ascochyta rabiei

The tissues were obtained after 4 weeks of culture on MS media and 14 days after inoculation with the pathogen, which had been grown on a chickpea medium. (A) Histological section in a callus of the FLIP84-92 C genotype. Parenchymal cells with small nuclei; persistence of xylem conducting vessels. Absence of pathogen fruiting bodies in tissues. (B) Histological section in a callus induced from leaflets of the ILC 32-97 genotype. Presence of pycnidia in neoformed tissues. (C) Histological section in a callus of the ILC 263 genotype, characterized by the abundance of fruiting bodies of Ascochyta rabiei: 1) Detail of a pycnidia showing the large number of pycnidiospores in the tissues; 2) High number of spores of Ascochyta rabiei, which caused cell lysis

Xy: xylem; Pyc: pycnidia; Sp: spores

\section{Discussion}

In order to optimize callogenesis in Cicer arietinum and to circumvent the recalcitrant response of the species to in vitro culture, a study of the effect of a few factors governing callogenesis was undertaken. The differences in the callogenesis rate were mainly due to the hormonal balance, as well as to the concentration of each growth regulator. These two factors have a direct influence on the callogenesis rate and are decisive for the optimization of the callogenic potential of Cicer arietinum (Shahab-ud-din et al., 2011). Notably, the combination of $2 \mathrm{mg}$ of IAA with $2 \mathrm{mg}$ of kinetin induced a rather interesting callogenesis rate, of about $80 \%$, considering the recalcitrant nature of the tissues of Cicer arietinum (Sani and Mustapha, 2010).This rate was recorded in all the genotypes, as well as with the different explants that were tested, which contradicts the 
results of Khan et al. (2011), who reported that the response of two native chickpea genotypes, namely 'KK1' and 'Hassan-2 K', subjected to in vitro culture conditions identical to those of the present study, expressed different callogenic abilities.

Although the in vitro reactivity of chickpea explants is strongly related to the growth regulators used and their concentration in the medium, the type of hormones used for the targeted morphogenetic orientations differs from one tissue to another according to the metabolic status of each hormone (Altaf et al., 1999). According to Bharathi and Elavarasi (2012), the choice of hormones is more decisive for the induction of callogenesis than their concentration. The two hormone types used in the present study (i.e., auxins and cytokinins) are well-known for their effect on the induction of cell proliferation and the orientation of the morphogenic program towards a specific organization (Gautheret, 1959; Bouabdallah, 1986; Zryd, 1988). Furthermore, they can act in synergy or antagonism (Jones and Ljiung, 2011). Auxins induce cell dedifferentiation (Boxus, 1995), are essential for the various signals leading to DNA synthesis, and, thus, ensure the strong mitotic activity of neoformed tissues (Gautheret, 1959; Neumann et al., 2009). As for cytokinins, they enable cell division and play a decisive role to stimulate the totipotency of auxins (Gautheret, 1959; Sané et al., 2012).

As mentioned previously, the hormonal combination of $2 \mathrm{mg}$ of IAA with $2 \mathrm{mg}$ of kinetin generated high rates of callogenesis, regardless of the genotype or the explant type, resulted in green, compact calluses with satisfactory growth. Likewise, Neelman et al. (1986) used the same hormones (i.e., IAA and kinetin), although with other concentrations and combined with another auxin (Naphthalene acetic acid), and obtained callus from Cicer arietinum explants of cotyledons, hypocotyls, and roots. According to Altınkut Uncuoğlu et al. (1997), the same hormones (IAA and kinetin) used at concentrations of $0.2 \mathrm{mg} \mathrm{L}^{-1}$ and $0.5 \mathrm{mg} \mathrm{L}^{-1}$ and with the addition of another cytokinin (benzyl adenine) resulted in a rate of callogenesis of $85 \%$. Furthermore, similar results have been reported by Sagare et al. (1993), Huda et al. (2003), Zare Mirakabad et al. (2011), Aasim et al. (2011), and Sani and Mustapha (2010), which indicates that the combination of these two hormones is favorable to induce dedifferentiation and cell proliferation in Cicer arietinum.

Based on the callus-pathogen interaction, we found that the effect of Ascochyta rabiei on callus is variable and relative to the resistance or sensitivity of the genotype. Singh and Singh (1990) reported that the growth of Neovossia indica on the surface of the callus of wheat embryos began within 2 days after inoculation. However, this time lag may be very short, of only a few hours, as in the case of Phytophthora cambivora, for which spore germination begins 3 hours after inoculation in the callus of a susceptible genotype of Castanea sativa (Casares et al., 1994).

The pathogen developed differently in contact with the tissues of the different genotypes.). As for the calluses from the 'ILC 32-97' genotype, the fruiting bodies (pycnidia and pycnidiospores) were present in the periphery of the tissues in reduced numbers, hence this genotype was considered tolerant to the pathogen. Finally, fruiting bodies were predominant in the histological sections of the calluses from the 'ILC 263' genotype and were present in the periphery of the tissues as well as in the intercellular space, leading to cell lyses in some cases, which confirmed the high sensitivity of this genotype.

Numerous studies on host-pathogen interaction have shown that resistance and susceptibility genes are expressed both in the whole plant and in a reduced pathosystem of a tissue or cell culture (Ingram, 1967; Gallão et al., 2007).

Heiler et al. (1995) reported that resistance does not alter spore germination stages, based on the presence of hyphae growth, regardless of the genotype that is tested (i.e., resistant, tolerant, or susceptible to the pathogen). This is consistent with the results obtained from the invasion of the external surfaces of the callus by hyphae of Ascochyta rabiei in the present study. Indeed, Kavousi et al. (2009) have reported that the expressionin Cicer arietinum of resistance genes to Ascochyta rabiei occurs after $48 \mathrm{~h}$ of infection. This is the time required to trigger numerous reactions in response to the parasite, after which the calluses of the 'FLIP 84-92 C' genotype develop a defense reaction characterized by a limited growth of hyphae compared to other genotypes. This resistance response is also observed in several host-parasite pairs, such as Beta vulgaris and 
Peronospora farinosa f. sp. betae (Ingram and Joachim, 1971), Fusarium oxysporum f. sp. ciceri infecting different organs of Cicer arietinum (Kunwar et al., 1989), and Nicotiana tabacum and Phytophthora parasitica var. nicotianae (DeZoeten et al., 1982). Moreover, a similar reaction has been observed in several resistant woody plants grown in vitro and inoculated with parasites (McComb et al., 1987; Jang and Trainter, 1990; Dai et al., 1995; Krause et al., 1996). According to Ameziane El Hassani (1981), during a resistance reaction between Cicer arietinum and Ascochyta rabiei, mycelial proliferation through the host cells is stopped by the formation of a band called the "boundary zone", where cells accumulate phenolic compounds to defend themselves. These compounds play an important role in plant resistance to biotic stress. Notably, Kessmann and Barz (1987) and Weidmann et al. (1991) have described the same behavior in cell cultures of Cicer arietinum inoculated with Ascochyta rabiei.

\section{Conclusions}

The hormonal combination of $2 \mathrm{mg}$ of IAA with $2 \mathrm{mg}$ of kinetin optimized callogenesis, regardless of the different explants (stems and leaflets) or the different genotypes of Cicer arietinum. Therefore, we can conclude that callogenesis in the explants from the three genotypes that were studied depends on the composition of the culture medium, in terms of growth regulators and their concentration. With the aim of selecting chickpea genotypes resistant to anthracnose, the use of a callus-pathogen pathosystem has made it possible to elucidate some parameters governing this interaction. Specifically, this green biotechnology tool that is in vitro tissue culture has allowed us to determine a Cicer arietinum genotype resistant to Ascochyta rabiei, namely the 'FLIP 84-92 C' genotype.

\section{Authors' Contributions}

Conceptualization and Methodology: YB; Resources and Software: KH and SG; Validation: YB; Visualization: YB, KH and SG; Writing - original draft: YB and KH.

All authors read and approved the final manuscript.

\section{Acknowledgements}

Authors would like to thank Pr. Louiza Bouabdallah and Pr. Zohra Ighilhariz for their advice and assistance. This research received no specific grant from any funding agency in the public, commercial, or notfor-profit sectors.

\section{Conflict of Interests}

The authors declare that there are no conflicts of interest related to this article.

\section{References}

Aasim M, Day S, Rezaei F, Hajizadeh M, Mahmud, ST, Ozcan S (2011). In vitro shoot regeneration from preconditioned explants of chickpea (Cicer arietinum L.) cv. Gokce. African Journal of Biotechnology 10(11):2020-2023. https://doi.org/10.5897/AJB10.823

Altaf N, Iqbal J, Salih Ahmad M. (1999). Tissue culture of Microsperma lentil(Lens culinaris mediki) cv. Massoor-85. Pakistan Journal of Botany 31(2):283-292. 
Altınkut Uncuoğlu A, Bajrovic K, Gozukirmizi N (1997). Regeneration and hairy root formation of chickpea using callus derived plantlets and seedlings. International Chickpea and Pigenpea Newsletter 20:30-31.

Ameziane El Hassani A (1981). Modalités d'expression de la résistance d'un cultivar de pois chiche (Cicer arietinum L.) à Ascochyta rabiei (Pass.) Lab. PhD Thesis, ENSA Rennes, France.

Anwar F, Sharmila P, Pardha Saradhi P (2010). No more recalcitrant: Chickpea regeneration and genetic transformation. African Journal of Biotechnology 9(6):782-797. https://doi.org/10.5897/AJB2010.000-3009

Bharathi P, Elavarasi N (2012). Preliminary studies of reactor system designed for cell suspension culture of chickpea (Cicer aritenum). International Journal of Chemical Sciences and Applications 3(1):223-231.

Bouabdallah L (1986). Culture in vitro du melon (Cocumis melo L.) et tantative d'application à l'étude de la fusariose. PhD Thesis, Paris Sud (Orsay) Univ, France.

Boxus P, Bercetche J (1995). Multiplication végétative: micropropagation, embryogenèse somatique. Agence universitaire de la francophonie prod., Paris.

Casares A, Gonzalez A, Sánchez Tamés R (1994). Ultrastructure of calli from resistant and susceptible chestnut inoculated with Phytophthora cambivora. Journal of Physiopathology 142:19-26. https://doi.org/10.1111/j.14390434.1994.tb00003.x

Daayf F, El Bellaj M, El Hassni M, J'Aiti F, El Hadrami L (2003). Elicitation of soluble phenolics in date palm (Phoenix dactylifera) callus by Fusarium oxysporum f. sp. albedinis culture medium. Environmental and Experimental Botany 49:41-47. https://doi.org/10.1016/S0098-8472(02)00048-5

Dai GH, Andary C, Mandolot Cosson L, Boubals D (1995). Involvement of phenolic compounds in the resistance of grapevine callus to downy mildew (Plasmapara viticola). European Journal of Plant Pathology 101:541-547. https://doi.org/10.1007/BF01874479

DeZoeten GA, Gaad G, Haberlach GT, Helgeson JP (1982). Infection of Tabacco callus by Phytophthora parasitica var. nicotinae. Phytopthology 72(7):743-746. https://doi.org/10.1094/Phyto-72-743

Gallão MI, Cortelazzo AL, Fevereiro MPS, de Brito ES (2007). Response to chitin in suspension-cultured Citrus aurantium cells. Brazilian Journal of Plant Physiology 19(1)69-76. https://doi.org/10.1590/S167704202007000100008

Gautheret RJ (1959). La culture des tissus végétaux: techniques et réalisations. Masson, Paris.

Heiler R, Esnault R, Lance C (1995). Physiologie végétale. 2. Développement. Masson (5th ed), Paris.

Huda S, Siddique NA, Khatun N, Rahman MH, Morshed M (2003). Regeneration of shoot from cotyledon derived callus of chickpea (Cicer arietinum L.). Pakistan Journal of Biological Sciences 6(15):1310-1313. https://doi.org/10.3923/pjbs.2003.1310.1313

Ingram DS (1967). The expression of R-gene resistance to Phytophthora infestans in tissue cultures of Solanum tuberosum. Journal of general Microbiology 49:99-108. https://doi.org/10.1099/00221287-49-1-99

Ingram DS, Joachim I (1971). The growth of Peronospora farinosa f. sp. betae and sugar beet callus tissues in dual culture. Journal of General Microbiology 69:211-220. https://doi.org/10.1099/00221287-69-2-211

Jang JC, Tainter FH (1990). Cellular response of Pine callus to infection by Phytophtora cinnamomi. Phytopathology 80:1347-1352. https://doi.org/10.1094/Phyto-80-1347

Jones B, Ljiung K (2011). Auxin and cytokinin regulated each other's levels via metabolic feedback loop. Plant Signalling \& Behavior 6(6):901-904. https://doi.org/10.4161/psb.6.6.15323

Kavousi HR, Marashi H, Mazafari J, Bagheri AR (2009). Expression of phenylpropanoid pathway genes in chickpea defense against Race 3 of Ascochyta rabiei. Plant Pathology Journal 8(3):127-132. https://doi.org/10.3923/ppj.2009.127.132

Kebmann H, Barz W (1987). Accumulation of isoflavone and pterocarpans phytoalexin in cell suspension culture of different cultivars of chickpea (Cicer arietinum). Plant Cell Report 6(1):55-59. https://doi.org/10.1007/BF00269739

Khan S, Ahmad F, Ali F, Khan H, Khan A, Swati ZA (2011). Callus induction via different growth regulators from cotyledon explants of indigenous chick pea (Cicer arietinum L.) cultivars KK-1 and Hassan-2K. African Journal of Biotechnology 10(40):7825-7830. https://doi.org/10.5897/AJB10.2378

Krause CR, Ichida JM, Shreider LR, Domir S (1996). Host parasite relationships to susceptible and resistant Elm callus cultures challenged with Ophiostoma ulmi (Buisman) Nannf. Journal of Environmental Horticulture 14(1):3338. https://doi.org/10.24266/0738-2898-14.1.33

Kunwar, IK, Satyaprasad K., Ramarao P (1989). Histopathology of chickpea plants infected with Fusarium oxysporum $\mathrm{f}$ sp ciceri. International Chickpea Newsletter 20:17-18. 
Lepoivre P (2003). Phytopathologie. De Boek (1st ed), Paris.

McComb JA, Hinch JM, Clarke AE (1987). Expression of field resistance in callus tissue inoculates with Phytophthora cinnamomi. Phytopathology 77:346-351. https://doi.org/10.1094/Phyto-77-346

Murashige T, Skoog F (1962). A revised medium for rapid growth and bioassays with tobacco tissue cultures. Physiologia Plantarum 15(3):443-497. https://doi.org/10.1111/j.1399-3054.1962.tb08052.x

$\mathrm{Naz}$ S, Ali A, Ahmed Siddique F, Iqbal J (2008). Somatic embryogenesis from immature cotyledons and leaf calli of chickpea (Cicer arietinum L.). Pakistan Journal of Botany 48(2):523-531.

Neumann KH, Kumar A, Imani J (2009). Plant cell and tissue culture- A tool in biotechnology. Basis and application, principles and practice. Springer- Verlag (1st ed), Berlin.

Ochatt S J, Atif RM, Patat- Ochatt EM, Jacas L, Conreux C (2010). Competence versus recalcitrance for in vitro regeneration. Notulae Botanicae Horti Agrobotanici Cluj-Napoca 38(2):102-108. https://doi.org/10.15835/nbha3824876

Sagare AP, Suhasini K, Krishnamurthy KV (1993). Plant regeneration via somatic embryogenesis in chickpea (Cicer arietinum L.). Plant Cell Reports 12:652-655. https://doi.org/10.1007/BF00232818

Sané D, Aberlanc- Bertossi F, Diatta LID, Guèye B, Daher A, Sagna M, Bogel A (2012). Influence of growth regulators on callogenesis and somatic embryo development in date palm (Phoenix dactylifera L.) sahalian cultivars. The Scientific World Journal 2012:1-8. https://doi.org/10.1100/2012/837395

Sani L, Mustapha Y (2010). Effect of genotype and 2, 4- d concentration on callogenesis in sugarcane (Saccharum spp. hybrids). Bayero Journal of Pure and Applied Sciences 3(1):238-240. https://doi.org/10.4314/bajopas.v3i1.58800

Savita V, Virk GS, Nagpal A (2010). Effect of explant type and different plant regulators on callus induction and plantlet regeneration Citrus jambhiri Lush. Environment and We: An International Journal of Science \& Technology 5:97-106.

Singh M, Singh A (1990). Growth and sporulation of Neovossia indica in wheat callus culture. Indian Phytopathology 29:113-115.

Sultan IN, Yousafzai A, Sattar FA, Ahmmad F, Ibrahim SM, Hassanullah M, Arif B (2011). The effects of different concentrations and combinations of growth regulators on the callus formation of potato (Solanum tubrosum) explants. Current Research Journal of Biological Sciences 3(5):499-503.

Weidemann C, Tenhaken R, Höhl U, Barz W (1991). Medicarpin and Maackiain-3-O glucoside -6'-O-malonate conjugates are constitutive compounds in chickpea Cicer arietinum L. cell culture. Plant Cell Reports 10:371374. https://doi.org/10.1007/BF00193162

Zaman MA, Manjur ABMK, Ahmed M, Islam MM (2010). Effect of 2,4-D on callus induction and subsequent morphogenesis in mature chickpea (Cicer arietinum L.) embryo culture. In: Islam AS, Haque MM, Sarker RH and Hoque MI (Eds). Proc. Sixth Intl. Plant Tissue Cult. \& Biotech. Conf., Dhaka (Bangladesh) pp 53-58.

Zare MH, Bagheri AR, Zare MM (2011). Efficient protocol for break impasses of regeneration via callus for 20 genotypes of chickpea. International Journal of Plant Production 4(2):115-128. https://doi.org/10.22069/ijpp.2012.688

Zrÿd JP (1988). Cultures de cellules, tissus et organes végétaux. Fondements théoriques et utilisations pratiques. Presses polytechniques romandes, Laussane.

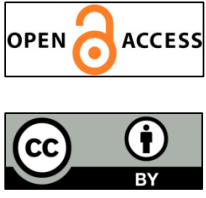

The journal offers free, immediate, and unrestricted access to peer-reviewed research and scholarly work. Users are allowed to read, download, copy, distribute, print, search, or link to the full texts of the articles, or use them for any other lawful purpose, without asking prior permission from the publisher or the author.

License - Articles published in Notulae Scientia Biologicae are Open-Access, distributed under the terms and conditions of the Creative Commons Attribution (CC BY 4.0) License.

(c) Articles by the authors; SHST, Cluj-Napoca, Romania. The journal allows the author(s) to hold the copyright/to retain publishing rights without restriction. 